\title{
WAVE INTERACTION OF PARTIALLY IMMERSED SEMICIRCULAR BREAKWATER SUSPENDED ON PILES USING FLOW-3D
}

\author{
ABO ZAID, A. A. ${ }^{1}$, MAHMOD, W.E. ${ }^{2}$, KORAIM, A. S. ${ }^{3}$, HEIKAL, E.M. ${ }^{4}$, FATH, H.E. ${ }^{5}$ \\ 1 Ph.D. student in Egypt-Japan University of Science and Technology(E-JUST), Egypt, ahmed.abozaid@ejust.edu.eg \\ 2 Egypt-Japan University of Science and Technology (E-JUST), Egypt, wael.elham@ejust.edu.eg \\ 3 Professor of harbor and marine structures, Faculty of Engineering, Zagazig University, Egypt, aymankoraim2004@yahoo.com. \\ 4 Professor of harbor and marine structures, Faculty of Engineering, Zagazig University, Egypt, Elsadekheikal@yahoo.com. \\ 5Egypt-Japan University of Science and Technology(E-JUST), Egypt, hassan.fath@ejust.edu.eg
}

\begin{abstract}
This paper experimentally investigates the wave transmission through partially immersed semicircular breakwater suspended on two rows of circular piles. Different wave and structure parameters have been investigated such as; incident wave height, wave length, wave period, breakwater draft and the clear gap between the supporting piles. Multiple Polynomial Regression (MPR) model is used to develop an empirical equation to calculate the transmission coefficient $\left(\mathrm{k}_{\mathrm{t}}\right)$ as a representative of the transmitted wave energy. In addition, a Flow-3D numerical study is carried out to simulate the transmitted wave hydrodynamics and verified against the experimental results. The numerical analysis shows good agreement with experimental results with an acceptable value of NRMSE. The results show that the transmission coefficient $\left(\mathrm{k}_{\mathrm{t}}\right)$ decreases by about $31 \%$ with increasing the relative wave length from 0.12 to 0.22 and wave steepness from 0.006 to 0.021 . Also, the transmitted coefficient $\left(\mathrm{k}_{\mathrm{t}}\right)$ decreases by about $25 \%$ with increasing the relative immersion depths from $0.25 \mathrm{~m}$ to $0.5 \mathrm{~m}$ and increases by about $16 \%$ for increasing of pile porosity value from 0.5 to 0.83 respectively.
\end{abstract}

KEWORDS: Semicircular, Suspended Breakwater, Wave Transmission, Flow-3D, MPR.

\section{INTRODUCTION}

Breakwaters are used for coastal protection from incident wave attack by reducing part of the wave energy before it reaches the shoreline to enhance safe vessel berthing and maneuvering. Different types of breakwater are widely used and developed around the world. The conventional types of these breakwater are such as Rubble mound and bottom seated concrete types. When water depth increases $(>4.0 \mathrm{~m})$, these structures become more expensive and difficult to build and need high seabed bearing capacity. In addition, these breakwater types interrupt alongshore sediment transport and cause erosion to beaches downcoast of the breakwater. These conventional types of breakwater stop the seawater exchange that is essential for fish migration and for maintaining the water quality. The increased wave reflection in front of breakwaters causes also navigation problems. On the other hand, floating breakwater have the drawbacks that; i-they are ineffective for long waves range of 4 to 6 seconds [1], ii-vulnerable to structural failure during storms, iii-require a high amount of maintenance, large roll and iv-sway motions may affect its performance to be used as a berth or a pier. In order to avoid these disadvantages, the floating breakwater are suspended on the pile system (Suspended breakwater) which give it advantages such as: a-Low construction cost and require less material; bease of construction, c-applicability in poor soil foundation and complex bathymetry, d-less interference to the ecosystem, e-allow flow exchange between water body and open sea, f-enabling fish migration and g-preservation of water quality and sediment transport activity. They can also be dismantled and relocated with minimum effort and without leaving permanent damage to the environment and reduce visual impact. They can also sustain and preserve the natural beauty of the beach and therefore they favorable to the beach users.

In recent years, research has been conducted to develop new configurations of a breakwater; the partial breakwater. This new concept consists of a solid body, completely or partially immersed, suspended on concrete piles or floating and fixed by cables. The total height of such caissons is far smaller than the water depth. So, this type of breakwater is partially permeable to the incoming ocean waves, especially for long waves which can be transmitted below the structure. Since most of the wave energy is concentrated close to the water surface in deep water, a structure located near the free surface or intersecting it can dissipate part of this energy or reflect it by diffraction. Several investigations were carried out on the rectangular caisson, the most classical shape, for example: (Drimer et al., 1992),(Tolba, 1998),(Koutandos et al., 2004) and (Koutandos et al., 2005). These studies showed that this structure can reflect the incident wave energy for small wave periods. More complex configuration, named BYBOP proposed by (Duclos et al., 2004), is more efficient in reducing transmitted wave. Table 1 summarizes the different shapes of semi immersed breakwater investigated by previous researchers. 
Table 1.Characteristics of different models of semi immersed breakwater studied by previous researchers.

\begin{tabular}{|c|c|c|c|c|}
\hline Reference & Structure type & Modeling type & Model shape & Main parameters ranges \\
\hline $\begin{array}{l}\text { (Neelamani and Vedagiri, } \\
\text { 2002) }\end{array}$ & $\begin{array}{l}\text { Partially immersed } \\
\text { twin vertical } \\
\text { barriers }\end{array}$ & $\begin{array}{l}\text { Experimental } \\
\text { (Regular and } \\
\text { random waves) }\end{array}$ & & $\begin{array}{c}\mathrm{d} / \mathrm{h}=0.285, \mathrm{~B} / \mathrm{h}=1, \mathrm{~h} / \mathrm{L}=0.12- \\
0.45, \mathrm{Hi} / \mathrm{h}=0.067-0.102 \\
\mathrm{~B}=0.7, \mathrm{~d}=0.2, \mathrm{~h}=0.7\end{array}$ \\
\hline $\begin{array}{l}\text { (Sundar and Subba Rao, } \\
\text { 2002) }\end{array}$ & $\begin{array}{c}\text { Quadrant front } \\
\text { face pile supported } \\
\text { breakwater }\end{array}$ & $\begin{array}{l}\text { Experimental } \\
\text { (Regular waves) }\end{array}$ & & $\begin{array}{l}\mathrm{d} / \mathrm{h}=0.31-0.45, \mathrm{P}=0.5-0.83 \\
\mathrm{~B}=1, \phi=0.06, \mathrm{~h} / \mathrm{L}=0.16-0.6\end{array}$ \\
\hline (Koutandos et al., 2005) & & $\begin{array}{l}\text { Experimental } \\
\text { regular/irregular }\end{array}$ & & $\mathrm{d} / \mathrm{h}=0.2-0.33, \mathrm{~B} / \mathrm{h}=1, \mathrm{Hi} / \mathrm{h}=0.1$ \\
\hline (Koutandos et al., 2004) & $\begin{array}{l}\text { Single fixed } \\
\text { (restrained) }\end{array}$ & $\begin{array}{l}\text { Mathematical } \\
\text { Boussinesq Equ. }\end{array}$ & & \\
\hline (Tolba, 1998) & $\begin{array}{c}\text { floating } \\
\text { breakwater }\end{array}$ & $\begin{array}{l}\text { theoretically and } \\
\text { experimentally }\end{array}$ & & $\begin{array}{c}\mathrm{d} / \mathrm{h}=0.25, \mathrm{~B} / \mathrm{h}=0.5 \\
\mathrm{~h} / \mathrm{L}=0.1-0.5\end{array}$ \\
\hline (Drimer et al., 1992) & & Analytical & & \\
\hline (Koutandos, 2009) & $\begin{array}{l}\text { vertical semi- } \\
\text { immersed slotted } \\
\text { barrier }\end{array}$ & Numerical & ain & $\begin{array}{l}\mathrm{d} / \mathrm{h}=0.5 \\
\mathrm{~h}=2.0\end{array}$ \\
\hline (Teh et al., 2011) & $\begin{array}{l}\text { Free surface } \\
\text { semicircular }\end{array}$ & Experimental & & $\mathrm{d} / \mathrm{h}=0.071-0.214 \mathrm{~h}=0.7$ \\
\hline $\begin{array}{l}\text { (Koraim and Salem, } \\
\text { 2012) }\end{array}$ & $\begin{array}{l}\text { Single semi- } \\
\text { immersed } \\
\text { horizontal half } \\
\text { pipes }\end{array}$ & Experimental & & $\begin{array}{c}\mathrm{d} / \mathrm{h}=0.5 \mathrm{~h} / \mathrm{L}=0.12-0.30 \\
\mathrm{~d}=0.1, \theta=90 \mathrm{o}, \mathrm{h}=0.20\end{array}$ \\
\hline (Duclos et al., 2004) & $\begin{array}{l}\text { Rectangular } \\
\text { caisson and } \\
\text { BYBOP }\end{array}$ & $\begin{array}{l}\text { Mathematical } \\
\text { RANS, Non Linear } \\
\text { Potential }\end{array}$ & & $\begin{array}{l}\mathrm{d} / \mathrm{h}=0.19 \\
\mathrm{~h}=0.8 \mathrm{~m}\end{array}$ \\
\hline (He and Huang, 2014) & $\begin{array}{c}\text { Suspended } \\
\text { oscillating water } \\
\text { column }\end{array}$ & Experimental & & $\begin{array}{c}\mathrm{d} / \mathrm{h}=0.25-0.5 ; \mathrm{Hi} / \mathrm{h}=0.0875 \\
\mathrm{Hi} / \mathrm{L}=0.01-0.03 \mathrm{~B}=\mathrm{h}=40\end{array}$ \\
\hline Present work & $\begin{array}{l}\text { Partially-immersed } \\
\text { semicircular } \\
\text { suspended on piles }\end{array}$ & $\begin{array}{l}\text { Experimental } \\
\text { and Numerical } \\
\text { (Flow 3d) }\end{array}$ & & $\begin{array}{c}\mathrm{d} / \mathrm{h}=0.25,0.5, \mathrm{~h}=0.4, \mathrm{~B}=0.1 \\
\mathrm{P}=0.5,0.83, \mathrm{~h} / \mathrm{L}=0.12-0.22 \\
\mathrm{Hi} / \mathrm{L}=0.006-0.021\end{array}$ \\
\hline
\end{tabular}

\section{EXPERIMENTAL TESTING}

\section{Experimental set-up}

The tested breakwater model was installed in the middle of the wave flume and situated between the inclined wave absorber and the wave generator. The module consists of a half-pipe manufactured from poly-vinyl chloride (PVC), with an outer diameter of $0.2 \mathrm{~m}$ and $0.01 \mathrm{~m}$ thickness. Vertical wood plate with a thickness of $0.01 \mathrm{~m}$ was fixed with the upper edge of the half pipe and the plate height was sufficient to prevent the wave overtopping on the breakwater. Two rows of PVC pipes with $0.05 \mathrm{~m}$ diameter $(\phi)$ and clear gap $(\mathrm{G})$ of 0.25 and $0.05 \mathrm{~m}$ were used as a supporter of the breakwater module as shown in Figure 1. The breakwater width (B) was kept constant at a value of $0.10 \mathrm{~m}$ and the tested breakwater drafts $(\mathrm{d})$ were 0.20 and $0.1 \mathrm{~m}$.

\section{Tests conditions}

Table 2 summarizes the tested values for different wave and breakwater parameters. Eight wave values were conducted with two breakwater draft (d) of 10 and $20 \mathrm{~cm}$ and two piles gap (G) of 5 and $25 \mathrm{~cm}$. The number of the experimental tests are 32runs.

\section{Wave gauge calibration}

Standard conductivity-type wave probe was used to measure the variations of water level with time. The wave probe comprises of two thin parallel stainless steel electrodes $(0.0015 \mathrm{~m}$ diameter, space $0.0125 \mathrm{~m}$ and length of $0.3 \mathrm{~m})$. The probe was connected to wave monitor module in the electronic console by a twin core flexible cable and delivered the output signals in the form of voltage data.Static calibration of the wave probe was carried out at the beginning of each set of experiments. Figure2 shows a linear relation between water level and output voltage resulting coefficient of determination $\left(\mathrm{R}^{2}=0.998\right)$. The linear equation was used in the programming of data acquisition card.The collected data 
during recording period converted into the water level by a simple computer program, resulting in the variation of water surface with time.

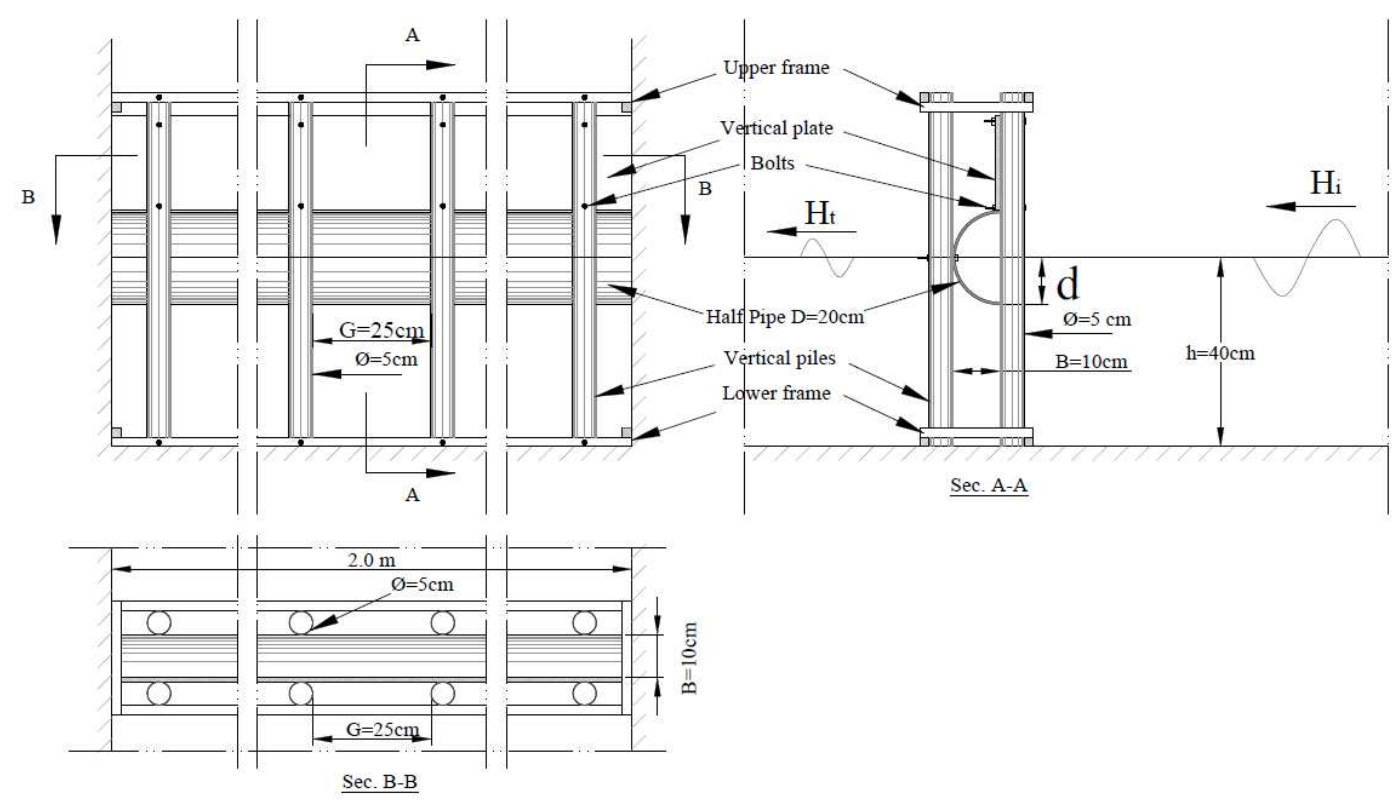

Figure 1. Different configuration of the tested breakwater.

Table 2.Experimental setup parameters of the breakwater model.

\begin{tabular}{ccc}
\hline Parameters & Unit & Ranges \\
\hline Wave periods (T) & $\mathrm{s}$ & $1.15-1.8$ \\
Wave length (L) & $\mathrm{m}$ & $1.81-3.35$ \\
Wave height (Hi) & $\mathrm{m}$ & $0.0207-0.038$ \\
Pile space (G) & $\mathrm{m}$ & $0.05-0.25$ \\
water depth (h) & $\mathrm{m}$ & 0.40 \\
breakwater width (B) & $\mathrm{m}$ & 0.10 \\
pile diameter ( $\phi)$ & $\mathrm{m}$ & 0.05 \\
outer pipe diameter (D) & $\mathrm{m}$ & 0.2 \\
Breakwater immersion depth (draft) (d) & $\mathrm{m}$ & $0.1-0.2$ \\
Relative wave length (h/L) & - & $0.12-0.22$ \\
Wave steepness (Hi/L) & - & $0.006-0.021$ \\
Relative immersion depth $(\mathrm{d} / \mathrm{h})$ & - & $0.25-0.5$ \\
Porosity of the lower part of breakwater $(\mathrm{P})$ & - & $0.5-0.83$ \\
\hline
\end{tabular}

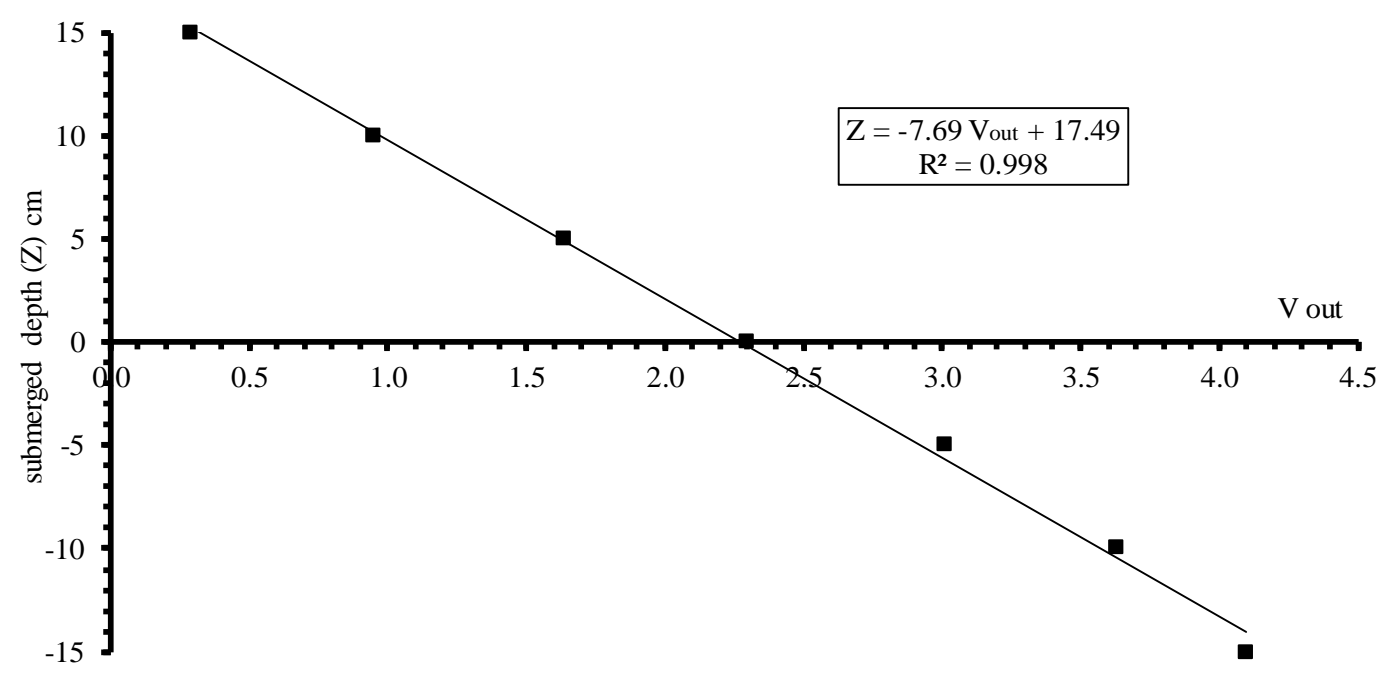

Figure 2.Calibration of the wave gauge. 


\section{Dimensional analysis}

The parameters affecting the transmission coefficient $\left(\mathrm{k}_{\mathrm{t}}=\mathrm{H}_{\mathrm{t}} / \mathrm{H}_{\mathrm{i}}\right)$ were investigated. These parameters are still water depth $(\mathrm{h})$, the unit weight of water $\left(\gamma_{\mathrm{W}}\right)$, the incident wave length $(\mathrm{L})$, the incident wave height $\left(\mathrm{H}_{\mathrm{i}}\right)$, the transmitted wave height $\left(\mathrm{H}_{\mathrm{t}}\right)$, the reflected wave height $\left(\mathrm{H}_{\mathrm{r}}\right)$, the acceleration of gravity $(\mathrm{g})$, the breakwater porosity $(\mathrm{P})$, breakwater immersion depth -draft (d) and the breakwater width (B). The relationship between these variables for the studied models is expressed as follows:

$$
\mathrm{f}\left(\mathrm{H}_{\mathrm{i}}, \mathrm{H}_{\mathrm{t}}, \mathrm{h}, \gamma_{\mathrm{w}}, \mathrm{L}, \mathrm{B}, \mathrm{d}, \mathrm{P}, \mathrm{g}\right)=0
$$

As the $\left(\gamma_{\mathrm{w}}\right),(\mathrm{g})$ and $(\mathrm{B})$ are constant, then the number of variables $=6$, selecting $\mathrm{H}_{\mathrm{i}}$ as repeating variable, number of dimensionless parameter $=6-1=5$ as follows:

$$
\pi_{5}=\mathrm{f}\left(\pi_{1}, \pi_{2}, \pi_{3}, \pi_{4}\right)(2)
$$

Then, $k_{t}=f\left(h / L, H_{i} / L, P, d / h\right)$

The effect of $\mathrm{h} / \mathrm{L}$ and $\mathrm{H}_{\mathrm{i}} / \mathrm{L}$ on $\mathrm{k}_{\mathrm{t}}$ is essentially need to investigate the hydrodynamic characteristics of the breakwater for coastal and deep-water regions and understand the performance of the breakwater for normal and extreme wave actions. Moreover, studying the effect of $\mathrm{P}$ and $\mathrm{d} / \mathrm{h}$ on $\mathrm{k}_{\mathrm{t}}$ is required to select the suitable structures configuration.

\section{Incident and transmitted wave heights measurement}

The dimensionless parameters were estimated from measuring the following variables in each individual experimental test. The incident wave heights $\left(\mathrm{H}_{\mathrm{i}}\right)$ was determined in the middle of the flume at the model location using the wave probe $\mathrm{P}_{1}$ (without breakwater model).The wavelength $(\mathrm{L})$ is calculated using the dispersion relationship based on the linear wave theory as follows: -

$$
L=\frac{g}{2 \pi} T^{2} \tanh (k h)(4)
$$

Where $\mathrm{k}$ is the wave number $(\mathrm{k}=2 \pi / \mathrm{L})$

The transmitted wave heights $\left(\mathrm{H}_{\mathrm{t}}\right)$ from the breakwater was measuredat the probe $\mathrm{P}_{2}$ behind the breakwater model at a distance of $1.5 \mathrm{~m}$ avoiding the effect of the turbulence caused by the wave breaking on the breakwater surface.(P1 and P2) locatins are shown in Figure 3 The transmission $\left(\mathrm{k}_{\mathrm{t}}\right)$ coefficient can be calculated as:

$$
\mathrm{k}_{\mathrm{t}}=\mathrm{H}_{\mathrm{t}} / \mathrm{H}_{\mathrm{i}}
$$

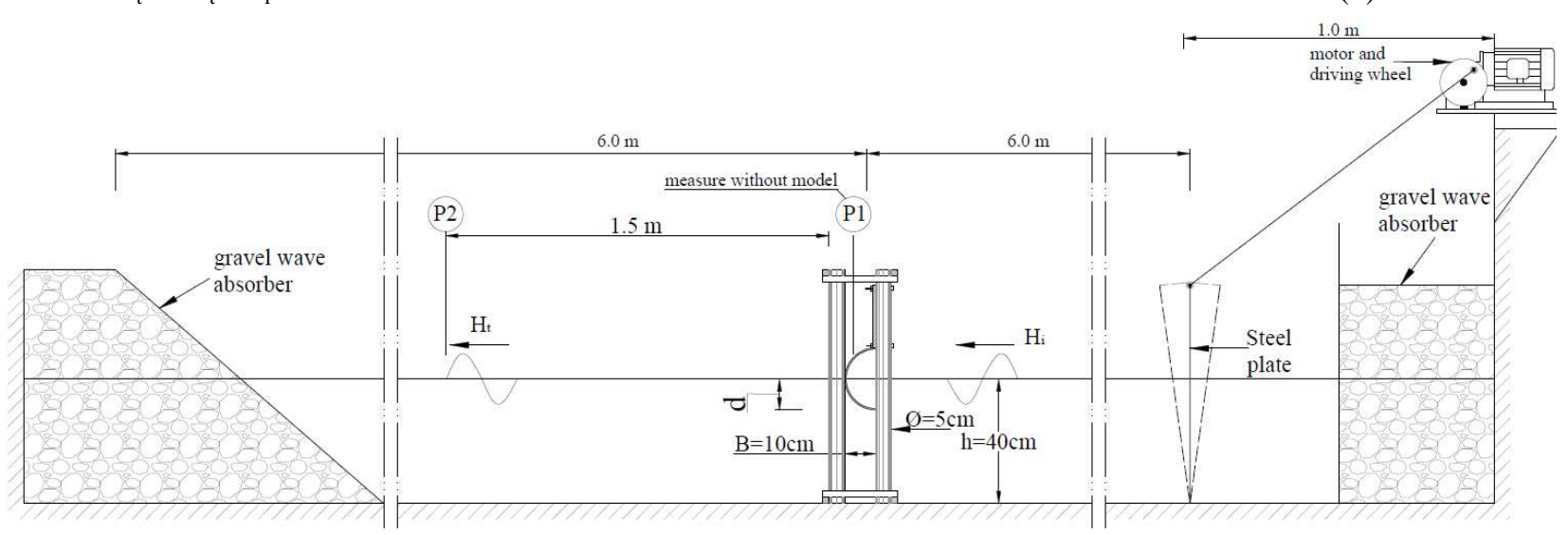

Figure 3. The wave flumes showing position of the breakwater model and the wave probes sites.

\section{Multiple Polynomial Regression Model (MPR)}

Using the above dimensionless parameters (See Equation 3), the regression analysis and the measured data, simple empirical equations for estimating the transmission coefficient for the different cases are developed. A Multiple Polynomial Regression (MPR) method was used to describe the behavior of a dependent variables $\left(\mathrm{k}_{\mathrm{t}}\right)$ that is related to the four independent variables $\mathrm{h} / \mathrm{L}, \mathrm{H}_{\mathrm{i}} / \mathrm{L}, \mathrm{P}, \mathrm{d} / \mathrm{h}\left(\pi_{1}, \pi_{2}, \pi_{3}, \pi_{4}\right)$ (Teh and Venugopal, 2013). The statistical program (SPSS Statistics 24 by IBM) was used to develop the empirical equations. The MPR technique was adopted to account for the nonlinearity of the data set and is expressed as:

$$
k_{t}=\left[\begin{array}{l}
a+a_{1} \Pi_{1}+a_{2} \Pi_{2}+a_{3} \Pi_{3}+a_{4} \Pi_{4} \\
a_{11} \Pi_{1}^{2}+a_{22} \Pi_{2}^{2}+a_{33} \Pi_{3}^{2}+a_{44} \Pi_{4}^{2}+ \\
a_{11} \Pi_{1} \Pi_{2}+a_{13} \Pi_{1} \Pi_{3}+a_{14} \Pi_{1} \Pi_{4}+ \\
a_{23} \Pi_{2} \Pi_{3}+a_{24} \Pi_{2} \Pi_{4}+ \\
a_{34} \Pi_{3} \Pi_{4}
\end{array}\right]
$$


Linear Regression analysis was usedand the predictors were selected by Enter method. The developed MPR model estimates the independent values $\left(\mathrm{k}_{\mathrm{t}}\right)$ by 14 predictors, shown in table 3 .

\section{Flow-3D numerical model}

Flow-3D is well known computational fluid dynamics(CFD) software, where the equations of motion are solved by the method of finite volume/finite differences in a Cartesian, staggered grid. The gravitational acceleration was set to $981\left[\mathrm{~cm} / \mathrm{s}^{2}\right]$. The viscosity and turbulence properties were set to be Newtonian Laminar flow which its result was more accurate and robust model available in the software.

\section{Meshing and geometry}

The semicircular model was exported in a stereo lithographic (stl) format to Flow-3D where the appropriate mesh could be generated. The accuracy of the results and the simulation time are effected by the cell size. So, it is important to minimize the amount of cells while including enough resolution to capture the important features of the geometry as well as sufficient flow details. For these reasons, multi-block meshwas used in the simulations, where bigger size cells were usedat less geometric details domain, and the smaller size cells near more geometric complexity as shown in Figure4.

\subsubsection{Boundary and initial conditions}

The upstream boundary condition in $\mathrm{x}$ direction was set to wave boundary and the downstream boundary was a wall boundary with wave absorbing block. All other open boundaries were specified as symmetric. The Stock wave theory of $5^{\text {th }}$ order has been used in Flow-3D; the wave is characterized by the wave height $\left(\mathrm{H}_{\mathrm{i}}\right)$, wave length $(\mathrm{L})$ and wave period $(\mathrm{T})$. In addition, at initial $(\mathrm{t}=0)$ a fluid region with height of $40 \mathrm{~cm}$ was simulated.

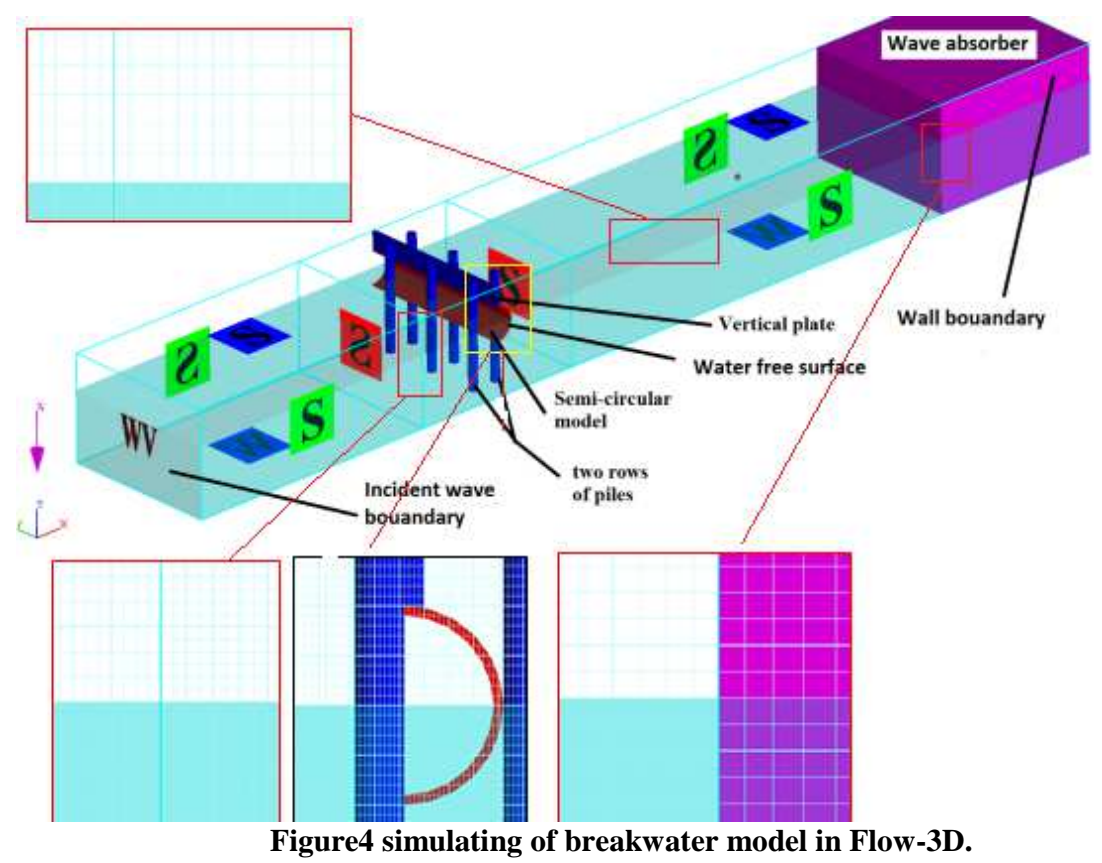

\section{RESULTS AND DISCUSSION}

the hydrodynamic efficiency of the partially immersed breakwater is affected by the wave and structure characteristics. The wave parameters are; wave length and height $\left(\mathrm{L}\right.$ and $\left.\mathrm{H}_{\mathrm{i}}\right)$, and the structural parameters are; the breakwater draft (d) and the space between piles (G). The dimensional analysis presents the hydrodynamic performance of the breakwater in the form of relationships between transmission coefficient $\left(\mathrm{k}_{\mathrm{t}}\right)$ and dimensionless parameters representing the wave and structure characteristics as presented in Equation 3. 


\section{Effect of Relative wave length $(\mathrm{h} / \mathrm{L})$ and Relative immersion depth $(\mathrm{d} / \mathrm{h})$}

Wave length is one of the most dominant parameters in the wave interaction with breakwater. In present study, the relative wave length $(\mathrm{h} / \mathrm{L})$ represents more the effect of wave length since the still water depth (h) was kept constant throughout the experiments. The variation of transmission coefficient $\left(k_{t}\right)$ as a function of $(h / L)$, is presented in Figure5 for relative immersion depth $(\mathrm{d} / \mathrm{h})$ ranges from 0.25 to 0.5 at piles porosity $(\mathrm{P})$ equal 0.5 and 0.83 . Figure5 shows that by increasing of $(\mathrm{h} / \mathrm{L}), \mathrm{k}_{\mathrm{t}}$ decreases for all values of $(\mathrm{d} / \mathrm{h})$. For example, at $\mathrm{d} / \mathrm{h}=0.25$ and $\mathrm{P}=0.5, \mathrm{k}_{\mathrm{t}}$ decreases by $36 \%$ with $(\mathrm{h} / \mathrm{L})$ increases from 0.12 to 0.22 . Thisis presumably explained by considering the water particle motions. For shorter wave length, h/L increases, the water particles velocity and acceleration increase and after interaction with the breakwater. The water particles velocity and acceleration suddenly change then the resulted turbulence causes low wave transmission. While the breakwater width is not enough to effectively disturb the orbital cycle for longer wave length. Then, its hydrodynamic performance reduces for the lower value of $\mathrm{h} / \mathrm{L}$.

The variation of transmission coefficient, $k_{t}$, with respect to $(d / h)$ is also shown in Figure5 for relative wave length $(\mathrm{h} / \mathrm{L})$ ranges from 0.12 to 0.22 at piles porosity $(\mathrm{P})$ equal 0.5 and 0.83 . For all values of $(\mathrm{h} / \mathrm{L})$, by increasing of $(\mathrm{d} / \mathrm{h}), \mathrm{k}_{\mathrm{t}}$ decreases. For example, at $\mathrm{h} / \mathrm{L}=0.12$ and $\mathrm{P}=0.5, \mathrm{k}_{\mathrm{t}}$ decreases by $14 \%$ with $(\mathrm{d} / \mathrm{h})$ increases from 0.25 to 0.5 . This may be attributed to the increase of $(\mathrm{d} / \mathrm{h})$, the area that the water passes through decreases then the transmitted wave energydecreases.

\section{Effect of piles porosity (P)and Wave steepness (Hi/L)}

The variation of the transmission coefficient, $k_{t}$ with respect to $(P)$ is shown in Figure6 for wave steepness $\left(\mathrm{H}_{\mathrm{i}} / \mathrm{L}\right)$ ranges from 0.006 to 0.021 at $(\mathrm{d} / \mathrm{h})$ equal 0.5 and 0.25 . Figure6 shows that by increasing of $(\mathrm{P}), \mathrm{k}_{\mathrm{t}}$ increases for all values of $\left(\mathrm{H}_{\mathrm{i}} / \mathrm{L}\right)$. For example, at $\mathrm{H}_{\mathrm{i}} / \mathrm{L}=0.006$ and with $(\mathrm{P})$ increases from 0.5 to $0.83, \mathrm{k}_{\mathrm{t}}$ increases by $18 \%$ for $\mathrm{d} / \mathrm{h}=0.5$. This may be attributed to the increase of $(\mathrm{P})$, the area that the water passes through increases then the transmitted wave energy increases.

The variation of the transmission coefficients, $k_{t}$ a function of wave steepness $\left(H_{i} / L\right)$, is presented in Figure6 for piles porosity $(\mathrm{P})$ ranges from 0.5 to 0.83 at relative immersion depth $(\mathrm{d} / \mathrm{h})$ equal 0.5 and 0.25 . Figure6 shows that by increasing of $\left(H_{i} / L\right), \mathrm{k}_{\mathrm{t}}$ decreases for all values of $(\mathrm{d} / \mathrm{h})$. For example, at $\mathrm{d} / \mathrm{h}=0.5$ and with $\left(H_{i} / L\right)$ increases from 0.006 to $0.021, \mathrm{k}_{\mathrm{t}}$ decreases by $58 \%$ for $\mathrm{P}=0.5$.
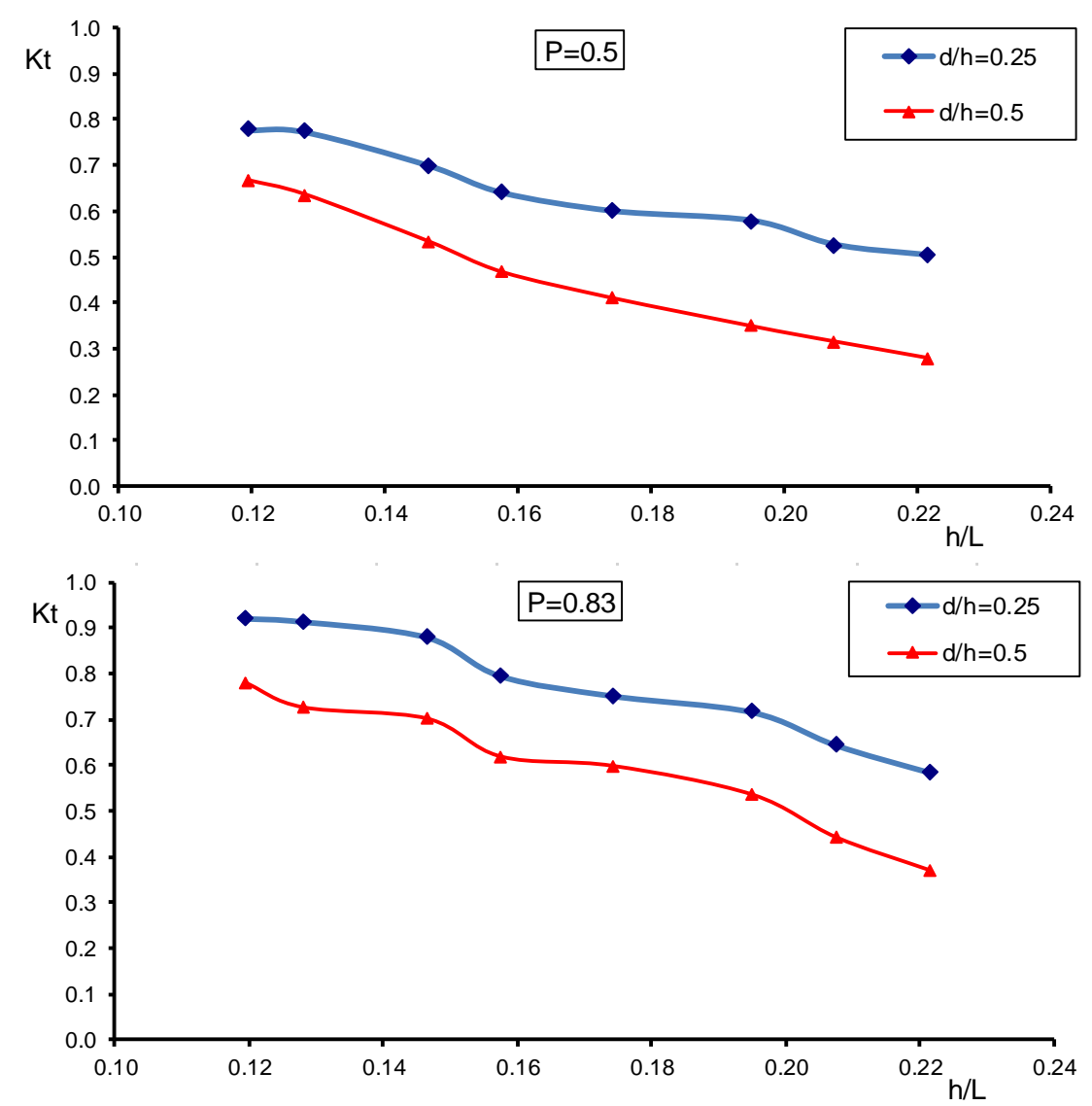

Figure5. Effect of Breakwater draft ratio $(\mathrm{d} / \mathrm{h})$ on the transmission coefficients as a function of relative wave length (h/L) when $P=0.5$ and 0.83 . 

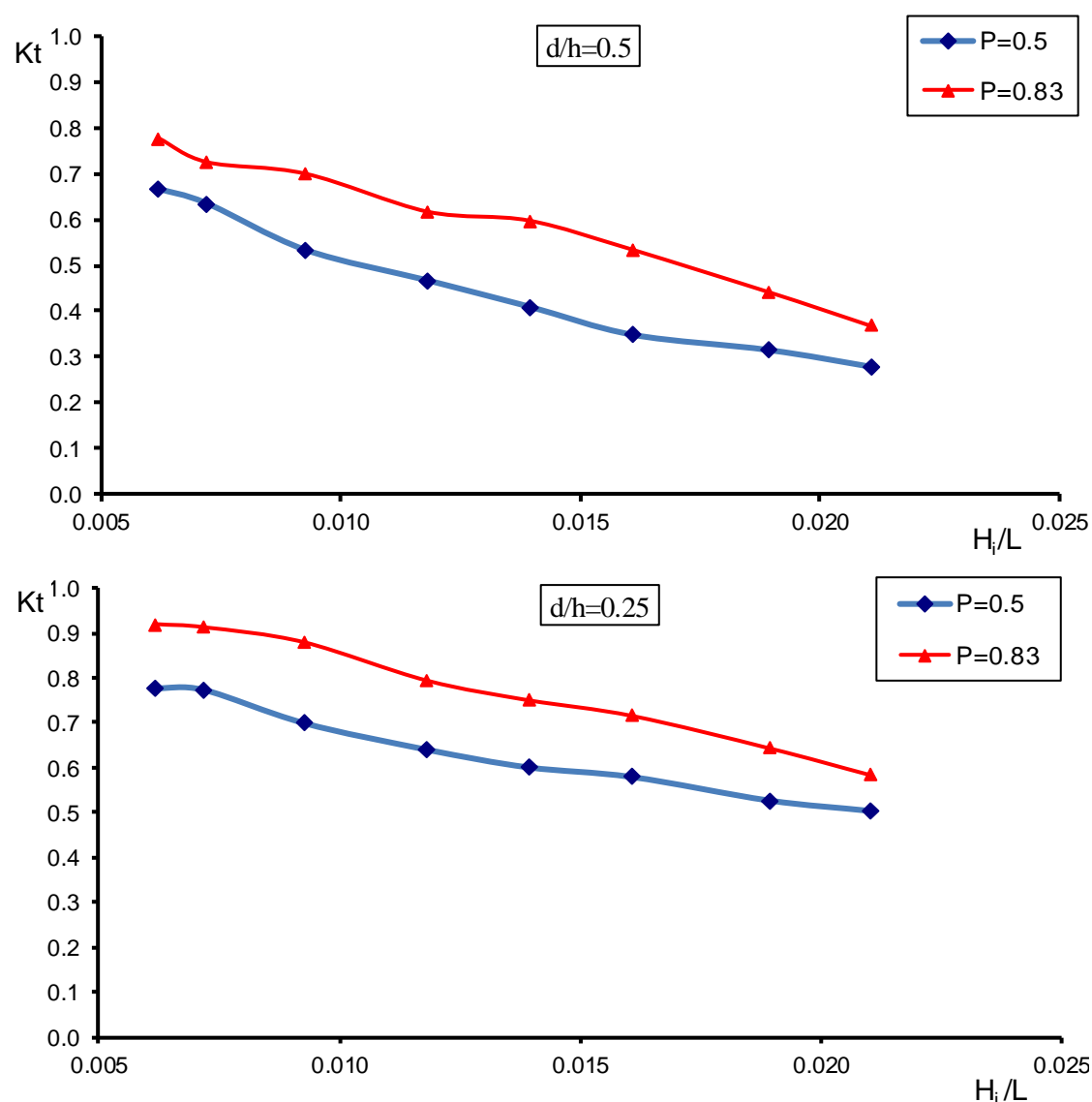

Figure6. Effect of pile porosity $(P)$ on the different hydrodynamic coefficients as a function of relative wave length $(\mathrm{h} / \mathrm{L})$ for a) $d / h=0.25$ and $b) d / h=0.5$.

\section{CALIBRATION OF MPR MODELS}

Table 3 presents the evaluation of coefficients values for MPR model using Stepwise method. while, Table 4 shows assessment of residuals analysis of transmission coefficient between calculated by MPR model and measured values.It can be observed that the equations over-predict and under-predict the transmission coefficient by values $\leq$ \pm 0.03 . Figure 7 shows the comparison between the measured and the calculated transmission coefficient $\left(k_{t}\right)$ of the breakwater using MPR model. A good agreement is obtained between the measured and the calculated transmission coefficient.

Table 3. Evaluation of coefficients values of parameters for MPR model

\begin{tabular}{ccc} 
Coefficient & parameter & value \\
\hline a & constant & 1.39 \\
a1 & h/L & -6.19 \\
a2 & Hi /L & 36.5 \\
a3 & d/h & - \\
a4 & $\mathrm{P}$ & -1.04 \\
a11 & $(\mathrm{h} / \mathrm{L}) 2$ & -0.27 \\
a22 & $(\mathrm{Hi} / \mathrm{L}) 2$ & 1329 \\
a33 & $(\mathrm{d} / \mathrm{h}) 2$ & 0.64 \\
$\mathrm{a} 44$ & $(\mathrm{P}) 2$ & - \\
$\mathrm{a} 12$ & $(\mathrm{~h} / \mathrm{L})(\mathrm{Hi} / \mathrm{L})$ & -154 \\
$\mathrm{a} 13$ & $(\mathrm{~h} / \mathrm{L})(\mathrm{d} / \mathrm{h})$ & -12.07 \\
$\mathrm{a} 14$ & $(\mathrm{~h} / \mathrm{L})(\mathrm{P})$ & 18.95 \\
$\mathrm{a} 23$ & $(\mathrm{Hi} / \mathrm{L})(\mathrm{d} / \mathrm{h})$ & 60 \\
$\mathrm{a} 24$ & $(\mathrm{Hi} / \mathrm{L})(\mathrm{P})$ & -136 \\
$\mathrm{a} 34$ & $(\mathrm{~d} / \mathrm{h})(\mathrm{P})$ & 0.09 \\
\hline
\end{tabular}


Table 4.Residuals analysis of MPR model.

\begin{tabular}{ccccc}
\hline Residual $=$ & \multicolumn{2}{c}{$\mathrm{d} / \mathrm{h}=0.5$} & \multicolumn{2}{c}{$\mathrm{d} / \mathrm{h}=0.25$} \\
measured-calculated & $\mathrm{P}=0.83$ & $\mathrm{P}=0.5$ & $\mathrm{P}=0.83$ & $\mathrm{P}=0.5$ \\
\hline RMSE x $\left(10^{-2}\right)$ & 1.601 & 1.674 & 0.961 & 1.317 \\
Min Res. & -0.02 & -0.028 & -0.016 & -0.019 \\
Max Res. & 0.03 & 0.024 & 0.013 & 0.02 \\
NRMSE & 0.04 & 0.045 & 0.03 & 0.046 \\
\hline
\end{tabular}

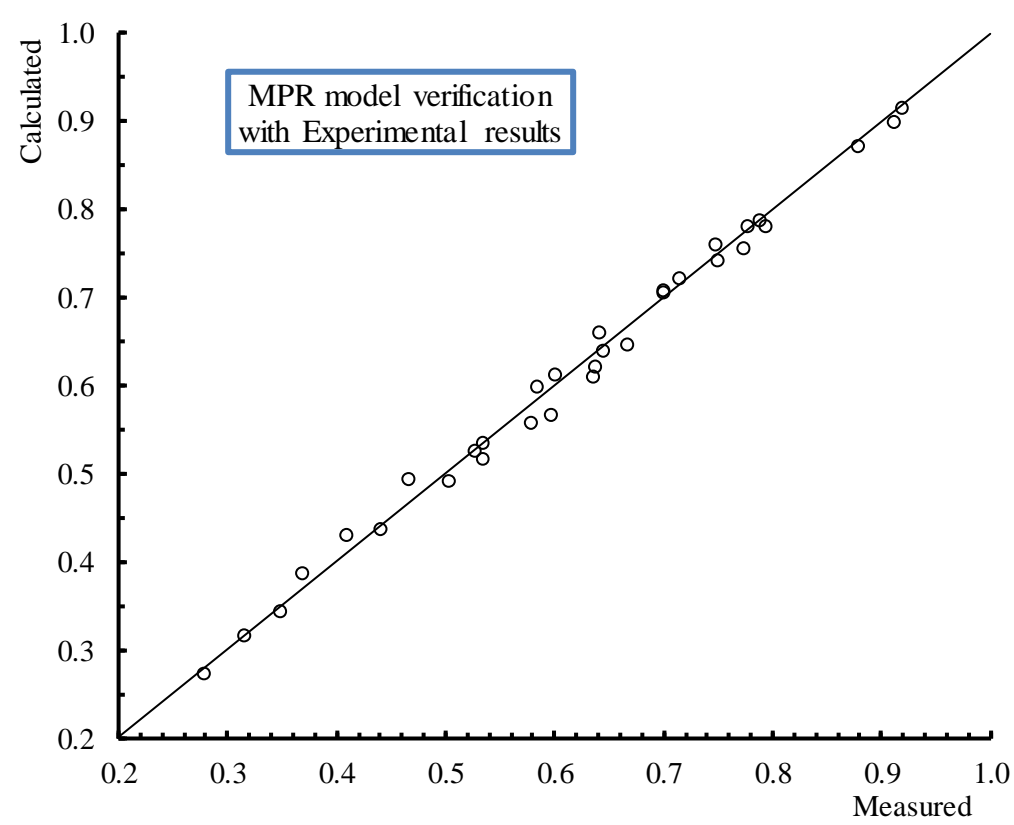

Figure 7.Comparison between calculated and experimental transmission coefficients results for MPR model.

\section{VALIDATION OF NUMERICAL RESULTS}

Figure8 shows data sample of the water elevation variation at location (P2) which represent the transmitted wave $\left(\mathrm{H}_{\mathrm{t}}\right)$. The figure presents the validation between experimental and numerical results for $\mathrm{d} / \mathrm{h}=0.25, \mathrm{P}=0.83, \mathrm{Hi}=0.038 \mathrm{~m}$ and $\mathrm{T}=1.15 \mathrm{~s}$. An acceptable agreement, between Flow-3D numerical and experimental results, can be observed.

Figure 9 presents a comparison between the measured and the calculated transmission coefficient $\left(\mathrm{k}_{\mathrm{t}}\right)$ of the breakwater using Flow-3D model. A good agreement is obtained between the measured and the calculated transmission coefficient.

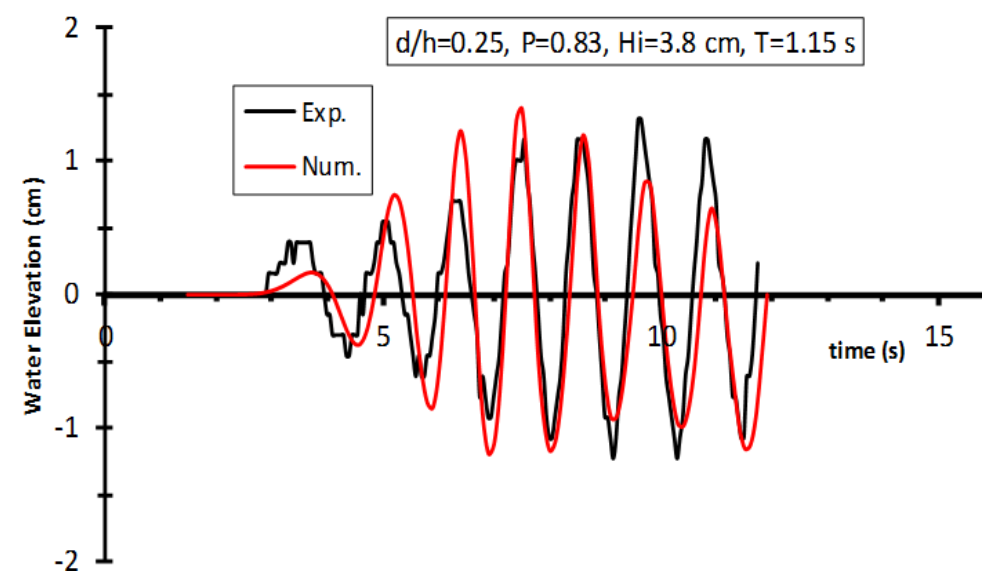

Figure8. variation of water elevation with time @ P2 for experimental and numerical results. 


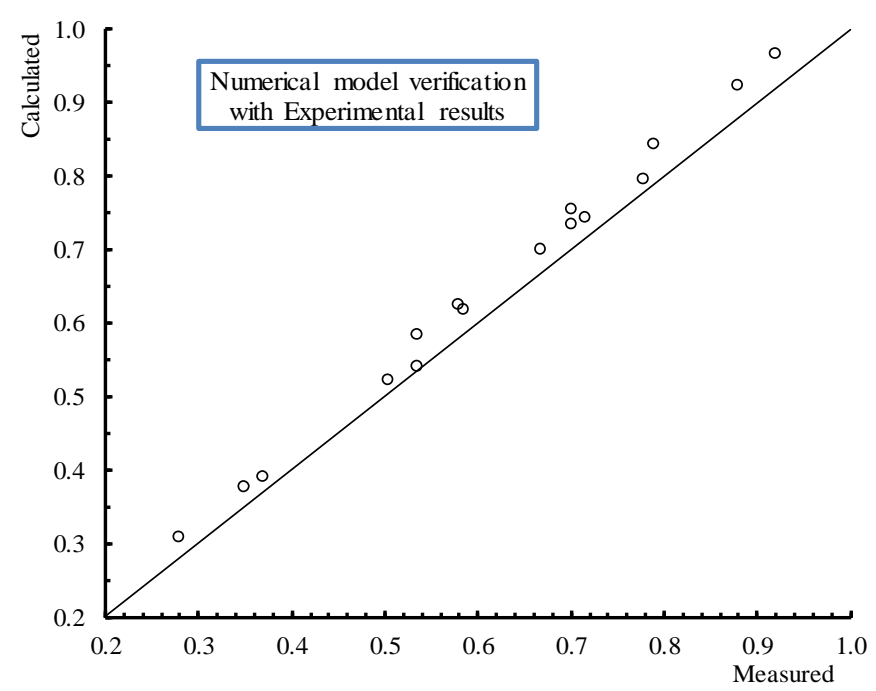

Figure9. comparison between numerical and experimental transmission coefficients results for Flow-3D model.

Table 5 shows assessment of residuals analysis of transmission coefficient between calculated Flow-3D and experimental values.It can be observed from the figure that Flow-3D model partially over-predict the transmission coefficient by values less than -0.06 .

Table 5.Residuals analysis of Flow-3D model.

\begin{tabular}{ccccc}
\hline Residual $=$ & \multicolumn{2}{c}{$\mathrm{d} / \mathrm{h}=0.5$} & \multicolumn{2}{c}{$\mathrm{d} / \mathrm{h}=0.25$} \\
measured-calculated & $\mathrm{P}=0.83$ & $\mathrm{P}=0.5$ & $\mathrm{P}=0.83$ & $\mathrm{P}=0.5$ \\
\hline RMSE x $\left(10^{-2}\right)$ & 3.63 & 3.775 & 4.084 & 3.946 \\
Min Res. & -0.058 & -0.051 & -0.048 & -0.055 \\
Max Res. & -0.009 & -0.030 & -0.030 & -0.019 \\
NRMSE & 0.087 & 0.097 & 0.122 & 0.143 \\
\hline
\end{tabular}

\section{COMPARISON WITH PREVIOUS STUDIES}

The experimental and numerical results of the present study as well as the empirical equation of transmission coefficientare compared with previous results for the studied semi-immersed breakwater.

Figures 10 presents the comparison between the results of the developed equation from MPR model, numerical and experimental results of the present study, and the different experimental and numerical results obtained by different published work presented in Table (1), as a function of $\mathrm{h} / \mathrm{L}$ for the suspended breakwater with $\mathrm{d} / \mathrm{h}=0.25$. The figure show that all calculated and measured $\mathrm{k}_{\mathrm{t}}$ coefficient decrease with $\mathrm{h} / \mathrm{L}$ increasing. Moreover, the MPR model and Flow$3 \mathrm{D}$ predicts the transmission coefficient with acceptable degree of accuracy.Figure 10presents the hydrodynamic performance of the different semi-immersed models, investigated by other published work of (Teh et al., 2011),(Suh et al., 2006), (Sundar and Subba Rao, 2002), (Koutandos et al., 2005), (He and Huang, 2014), (Duclos et al., 2004) and (Neelamani and Rajendran, 2002). The performance of the different models $\left(\mathrm{k}_{\mathrm{t}}\right)$ is plotted as a function of $\mathrm{h} / \mathrm{L}$. The characteristics of these experimental studies are shown in Table (1). The figure shows that high scatter in the performance of the different compared models. This can be attributed to the difference in the geometry and cross sections shape used in each case. The results trend shows that all the $\mathrm{k}_{\mathrm{t}}$ decrease with increasing $\mathrm{h} / \mathrm{L}$. Moreover, the present model gives smaller transmission values than (Suh et al., 2006) and(Teh et al., 2011) and larger values compared with others.

\section{CONCLUSIONS}

The wave transmission characteristic of a new shape of partially immersed breakwater is experimentally an numerically studied by using physical and Numerical models. The breakwater consists of a semicircular cross section suspended on two rows of circular piles, it was tested under different wave and structural parameters. In general, the proposed breakwater shows low transmission coefficients with increasing of the relative immersion depth $(\mathrm{d} / \mathrm{h})$ and decreasing of piles porosity $(\mathrm{P})$. Furthermore, increasing of both relative wave length $(\mathrm{h} / \mathrm{L})$ and wave steepness $\left(\mathrm{H}_{\mathrm{i}} / \mathrm{L}\right)$ cause lower transmission coefficients. Semicircular shape reduce the transmission slightly than rectangular shape especially for $\mathrm{h} / \mathrm{L}>0.16$. The results are compared with experimental and theoretical published work and shows a reasonable agreement. In addition, an empirical equation is developed for estimating the transmission coefficient of proposed breakwater. The results of this equation shows reasonable agreement with the experimental results. More investigations with different partially immersed breakwater shapes, under irregular, and obliquely incident waves are 
still required.

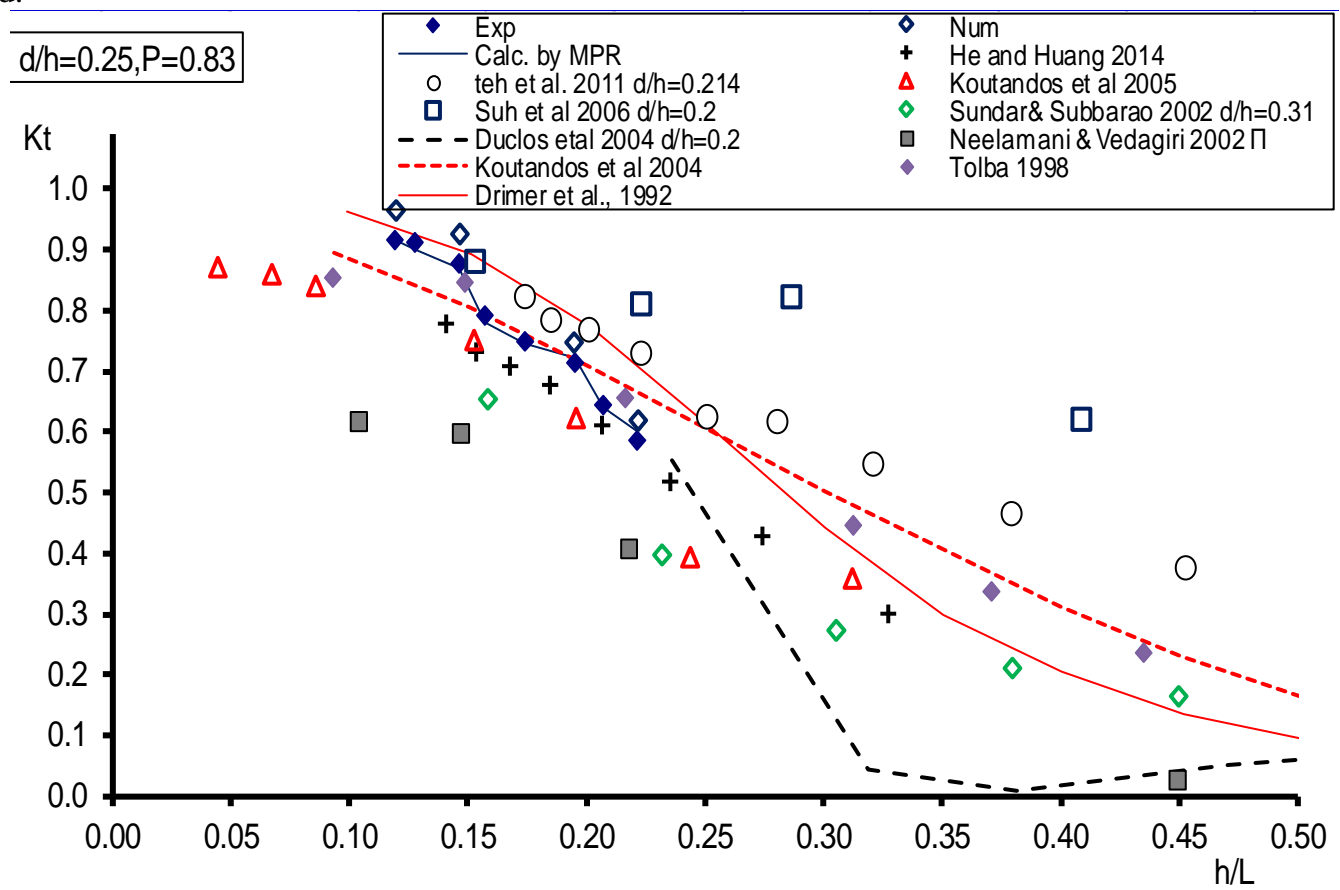

Figure 10. Comparison between the results of the present suspended breakwater model and the different results obtained from previous works when $\mathrm{d} / \mathrm{h}=\mathbf{0 . 2 5}$ and $\mathrm{P}=\mathbf{0 . 8 3}$.

\section{ACKNOWLEDGEMENT}

The first researcher is supported by a scholarship from the Mission Department for the Government of Egypt which is gratefully acknowledged. Second appreciative acknowledge to Harbor Engineering Lab. In water and water Engineering Dpt.- Zagazig University for permitting the author to carry out the experimental work of this paper. Last, but not least I am thankful to Egypt-Japan University of Science and Technology (E-JUST) and Japan International Cooperation Agency (JICA) for offering the tools and equipment needed for the research work.

\section{REFERENCES}

Drimer, N., Agnon, Y., Stiassnie, M., 1992. A simplified analytical model for a floating breakwater in water of finite depth. Appl. Ocean Res. 14, 33-41.

Duclos, G., Josset, C., Clément, a. H., Gentaz, L., Colmard, C., 2004. Hydrodynamic Efficiency of a New Design of HalfSubmerged Breakwater Compared to a Rectangular Caisson. J. Waterw. Port, Coastal, Ocean Eng. 130, 127-133.

He, F., Huang, Z., 2014. Hydrodynamic performance of pile-supported OWC-type structures as breakwaters: An experimental study. Ocean Eng. 88, 618-626.

Koraim, A.S., Salem, T.N., 2012. The hydrodynamic characteristics of a single suspended row of half pipes under regular waves. Ocean Eng. 50, 1-9.

Koutandos, E., Prinos, P., Gironella, X., 2005. Floating breakwaters under regular and irregular wave forcing: reflection and transmission characteristics. J. Hydraul. Res. 43, 174-188. doi:10.1080/00221686.2005.9641234

Koutandos, E. V., 2009. Hydrodynamics of vertical semi-immersed slotted barrier. WSEAS Trans. Fluid Mech. 4, 85-96.

Koutandos, E. V., Karambas, T. V., Koutitas, C.G., 2004. Floating Breakwater Response to Waves Action Using a Boussinesq Model Coupled with a 2DV Elliptic Solver. J. Waterw. Port, Coastal, Ocean Eng. 130, 243-255.

McCartney, B.L., 1985. Floating Breakwater Design. J. Waterw. Port, Coastal, Ocean Eng. 111, 304-318.

Neelamani, S., Rajendran, R., 2002. Wave interaction with “_”-type breakwaters. Ocean Eng. 29, 561-589.

Neelamani, S., Vedagiri, M., 2002. Wave interaction with partially immersed twin vertical barriers. Ocean Eng. 29, 215-238.

Suh, K.D., Shin, S., Cox, D.T., 2006. Hydrodynamic Characteristics of Pile-Supported Vertical Wall Breakwaters. J. Waterw. Port, Coastal, Ocean Eng. 132, 83-96.

Sundar, V., Subba Rao, B.V. V, 2002. Hydrodynamic pressure and forces on quadrant front face pile supported breakwater. Ocean Eng. 29, 193-214.

Teh, H.M., Venugopal, V., 2013. Performance evaluation of a semicircular breakwater with truncated wave screens. Ocean Eng. 70, $160-176$.

Teh, H.M., Venugopal, V., Bruce, T., 2011. Performance Analysis of a Semicircular Free Surface Breakwater,Proceedings of the 30th International Conference on Ocean, Offshore and Arctic Engineering.

Tolba, E.R., 1998. Behaviour of floating breakwaters under wave action. Ph.D. thesis , Civil engineering Dept.,Suez Canal. 